\title{
соціологія
}

UDC 316

\section{THE DECLINE AND FALL OF BRITISH POWER: 1945 TO 1963}

\author{
Chris Weston \\ PhD, President at Weston Consulting, \\ Warsaw
}

Using sources of social power by Mann, the article analyses the course and behavior of Great Britain in the political arena in the period from 1945 to 19963 when Britain's accession to the European Economic Community was honored by the President of France de Gaulle. Relying on the fifth source of social power as described by Mann, the analysis considers British political leaders in the determined period with a special emphasis on Attlee and Macmillan who significantly influenced British power during this period. As a consequence of the war, Great Britain was faced with decolonization processes, including India's independence struggles, and also sought to maintain its influence in the Middle East and South-East Asia. However, Great Britain fell into dependence on US aid under the Marshall Plan. Despite some success in establishing a security system and economic coordination with European countries, Great Britain failed to achieve the creation of a "close" project in Europe. This failure to demonstrate leadership had fatal consequences - the inability to play any role in the game set by other major economic forces. This article is the second in a series devoted to the study of the fall and decline of the power of Britain since 1945.

В статті проаналізовано за допомогою джерел соціальної влади Манна курс та поведінку на політичній арені Великої Британії в період з 1945 по 1963 роки, коли вступ Великої Британії до Європейської економічної спільноти був заветований Президентом Франції де Голем. Опираючись на п'яте джерело соціальної влади описане Манном, в аналізі розглядаються британські політичні лідери в зазначений період з особливим акцентом на Атлі та Макміллі, які суттєво вплинули на потугу Великої Британії в цей період. Як наслідок війни, Великобританія стикнулася із процесами деколонізації, зокрема змаганнями Індії за незалежність, а також намагалася підтримати свій вплив на Близькому Сході та у Південно-Східній Азії. Однак Великобританія потрапила у залежність від американської допомоги за планом Маршала. Не зважаючи на певні успіхи у створенні системи безпеки та економічної координації із європейськими країнами, Британії не вдалося досягти створення «близького» проекту Європи. Ця невдала спроба продемонструвати лідерство мала доленосні наслідки - нездатність грати будь-яку роль у грі, встановленій іншими великими економічними силами. Ця стаття $є$ другою у серії, присвяченій вивченню падіння та занепаду влади Британії з 1945 року.

В статье проанализированы с помощью источников социальной власти Манна курс и поведение на политической арене Великобритании в период с 1945 по 1963 годы, когда вступление Великобритании в Европейское экономическое сообщество было ветировано Президентом Франции де Голлем. Опираясь на пятый источник социальной власти, описанный Манном, в анализе рассматриваются британские политические лидеры в указанный период с особым акцентом на Атли и Макмилли, которые существенно повлияли на мощь Великобритании в этот период. В результате войны, Великобритания столкнулась с процессами деколонизации, в частности соревнованиями Индии за независимость, а также пыталась поддержать свое влияние на Ближнем Востоке и в Юго-Восточной Азии. Однако Великобритания попала в зависимость от американской помощи по плану Маршалла. Несмотря на определенные успехи в создании системы безопасности и экономической координации с европейскими странами, Британии не удалось достичь создания «близкого» проекта Европы. Эта неудачная попытка продемонстрировать лидерство имела судьбоносные последствия - неспособность играть какую-либо роль в игре, установленной другими крупными экономическими силами. Эта статья является второй в серии, посвященной изучению падения и упадка власти / Британии с 1945 года.

Key words: Great Britain, social power sources, leadership, India.

Formulation of the problem. The purpose of this paper is to examine, with the aid of the Sources of Social Power, as noted by Mann, the conduct and course of Britain from 1945 up to 1963 when Britain's entry to the European project (at the time, the EEC) was vetoed by French President De Gaulle. 
The sources of social power are as follows:

- Economic

- Political

- Military

- Ideological

Mann in the course of his four works on this has also outlined a fifth source of power - that of Leadership [16, p. 271]. The analysis therefore considers the British political leaders in the period in question with particular emphasis on Atlee and Macmillan who essentially bookend the period in question.

It will be noted that no preference is given to the leaders in question on political terms. All registered achievements of one form or another, although the Atlee administration probably achieved the most until Thatcher became premier in 1979 - a view endorsed by Lord Hennessey in his review of post war prime ministers.

But all of them essentially lacked a vision with respect to Europe and failed, in the paper's view, to fully take advantage of Britain's preeminent position in 1945 after Victory in Europe.

It is further argued that this was not the fault of inadequate intelligence available. Britain, by virtue of its intelligence services work during the war, particularly in signals intelligence, were fully appraised of the European project. Britain's political leaders all were dismissive of the project or thought it not a priority. Britain might have grasped the opportunity to exercise leadership of the project. It didn't and the paper seeks to convey that that almost led inevitably to poor leadership.

Further, it argues that a considerable amount of Britain's perceived sources of power - whether Military, Economic or Political - were illusory or essentially subsidised by the USA.

Thus, while not explicitly referring to Ideology, the reader is asked to digest the story in the paper and draw the inference that there was a belief in an imperial past that overlooked the fragile condition of its foundations. The game was up when India declared independence. Britain's search for stopgap financing from the USA and belief in wielding Military Power to retain its Economic Power was essential to fostering illusions and delusions of British power.

Those illusions and delusions still seem prevalent today.

Purpose of the article. To analyse through the sources of social power Manna course and behaviour in the political arena of Great Britain in the period from 1945 to 1963.

Basic material presentation.

\section{Britain and Its Empire in 1945.}

An important source of belief in Britain - and still prevalent today in the country post Brexit referendum - is the comforting sense that the country can "go it alone" as it appeared to do in May 1940 when Hitler had routed the allied forces in France and forced an evacuation of British and allied forces from Dunkirk. Thus, Britain stood alone and fought alone. The "Britain alone" myth - still embodied in films and books - was never quite supported by the reality given it could draw upon the full resources of men and material of the British Empire [10] - whether it be fighting men from Australia and New Zealand, oil from the Middle East, food from Australia and Canada as well as the full financial means and credit of this imperial enterprise. It should be noted, according to M Harrison [13, p.53], UK's overseas debts in middle 1945 for the Sterling area, i.e. British Empire, Eire and Middle East countries, amounted to $£ 2.7$ billion, of which $£ 1.7$ billion was owed to India, Burma and Middle East.

The "jewel in the crown" of the British Empire was India, which then encompassed what is now India, Pakistan and Bangladesh. India had provided a substantial amount of troops that had, in point of fact, substantially built the British Empire over the nineteenth century and fought its various colonial wars as well as the two world wars. At the time of its conquest by the British in the eighteenth century, the country is estimated to have accounted for almost $30 \%$ of the world's economic output. This had been drained off by the British - it was estimated by Arrighi that Britain derived over fifty years after the Battle of Plassey in 1757 up to $£ 1$ billion from its possession of India [2, p. 53]. Sufficient to buy national debt back from the Dutch and leaving Britain free from international indebtedness ahead of the Napoleonic Wars. As per Findlay: "without the accumulated credits from Indian transfers since 1757, Britain's financing of land warfare during the French wars could have been compromised" [11, p.275].

This continued throughout the war years with Britain accessing supplies for itself from the country which were not paid for. Indeed, this had extended into geopolitical needs when Britain secured food supplies in 1943-1944 for meeting the food needs of Greece - in which the British government had become interested as part of securing its interests in the Mediterranean and supporting royalist forces in a civil war against Communist backed partisans - which contributed to a disastrous famine in Bengal which claimed in excess of a million lives [19].

The US Subsidy of Britain

India became vitally important to British economic and financial interests after the war came to a close in August 1945 and ever more so in the light of the US decision to end lend - lease in September 1945 by President Truman. To give a sense of the importance of this major contribution to the British war 
effort, it should be noted that the high intensity (and expense) of modern war had led to the liquidation of British overseas investments by early 1940 (Britain had only declared war in September 1939) and this measure introduced by the then US President Roosevelt kept Britain fighting on with materials (including food and oil) that otherwise might have been denied to it. Lend lease amounted to US \$ 31.4 billion (or US $\$ 427$ billion in modern day terms). The final payment for amounts secured by Britain under this facility was only made in December 2006!

Furthermore, Britain's top economic advisor, John Maynard Keynes - who had played a key role in the 1944 Bretton Woods conference which led to the creation of the IMF and World Bank - had managed to secure a loan from the USA of US $\$ 3.75$ billion [18] which had largely gone towards maintaining the substantial British armed forces overseas in defense of its imperial interests.

The defense of British imperial interests was often tied to both perceived and actual vital economic interests, as much to maintaining military power and the intangible asset of imperial prestige. With the hasty decision to exit India - which might necessitate the commitment of a force greater than Britain possessed and the inevitability of being sucked into the communal clashes then engulfing India, which witnessed millions ethnically cleansed and at least one million killed, as the newly formed entities of India and Pakistan (West and East - the latter becoming Bangladesh in due course) emerged - British economic power lessened.

With this loss, Britain became ever more anxious to secure its remaining vital economic interests whether in Iran, Iraq and Kuwait, as represented by oil, or the tin mines and rubber plantations of Malaya [8, p. 56-57]. According to Curtis, citing official government documents: "Apart from rubber, the tin mining industry of Malaya is the biggest dollar earner in the British Commonwealth...70\% of the acreage of rubber estates was owned by European (primarily British) business interests. Malaya was the greatest material prize in South-East Asia." The UK needed dollar earnings from this source to pay for imports and maintain its financial position in the world.

We have noted in Iran the former grow in prominence in late 1950 and the coup jointly arranged by SIS/CIA in 1953 to remove the threat posed by nationalization of BP's oil interests.

The latter - the so called Malayan Emergency - was fought between 1948 and 1960 against largely Chinese inhabitants belonging to the Malayan Communist Party. Even with independence granted, Britain exercised considerable influence over the entities - Malaysia and Singapore - through its considerable economic interests.

\section{Britain and its European neighbors}

Britain and Europe as a whole were struggling at this time with Britain facing particularly strong headwinds of devoting considerable resources particularly of men to maintaining post war an empire (both formal and informal) upon which it relied on for foreign exchange to finance imports and staving off attacks on the value of sterling (whose high exchange rate would reduce the cost of imports); the tightening of rationing had not enamored the domestic electorate and had led to strikes; as well as contributing to securing interests in Europe i.e. occupation of a part of West Germany and West Berlin; assistance in the Greek civil war etc.

The provision by the USA at the beginning of April 1948 of US $\$ 12$ billion (in 2007 terms, US $\$ 140$ billion) under the European Recovery Plan (better known as the Marshall Plan) again helped provide an appropriate stopgap for Britain as well as the rest of Western Europe. The UK alone received the largest share of this aid $-26 \%$ - again a measure of the parlous conditions faced by the country [18, p.164]. Separate to this, the UK had received up to 1947 a further US $\$ 3.75$ billion from the USA. The country's Economic and Military Power was essentially being subsidized by the US over this period. And possibly its welfare state as well. According to A Cairncross, The British Economy since 1945, Blackwell, UK, 1995, p 80, the NHS was costing on average $£ 460$ million per annum in the last 3 years of the Labour government to 1951.

Of particular interest in the post war period is the British position vis a vis Europe, or at least the Western side given the emergence of what would later be termed the "Iron Curtain". British forces had been engaged in the Greek civil war; fought their way through Italy; and had fought alongside the US and indeed European allies in the liberation of Western Europe all the way to Berlin.

British maintained forces in occupation of Germany and indeed occupied a particular zone thereof. Britain had initiated tighter rationing at home to help parts of Western Europe to feed itself. Indeed, it had brought about a famine in its Indian "jewel" to help feed the European population to avoid a further collapse.

To add to this investment, it had brought together European counterparts to arrange the distribution of Marshall Aid to its neighbors; signed the Treaty of Brussels with a number of European countries - Belgium, the Netherlands, Luxembourg and France - which served as a precursor to the establishment of NATO [5]. Bevin was one of the true giants of 20th century Britain. A creator of one of Britain's largest trade unions and a Churchill appointed Minister of Labour during the Second World War. He has been rated as one of the better Foreign Secretaries (1945-1950) to have occupied this office. 
Its Military, Economic and Political power were surely in the ascendant in Europe (or at least the western part) even if this was, in part, caused by German prostration following the war.

A number of these neighbours would, like the British, be facing the liquidation of their own imperial interests upon which their own wealth had been built and which had faced destruction during the war.

\section{The Atlee Government: Opportunities missed}

The Atlee government of 1945-1951 is generally viewed as one of the most transformative British governments since the war [15] and has earned many plaudits the construction of a welfare state and, of course, the National Health Service; its first steps in constructing a European security and defence architecture and, albeit tentatively through the establishment of the OECD to run the Marshall Plan, an important role in coordinating western European economies.

The history of the Atlee administration is of a mix of effecting a transformation but also of firefighting as it sought to extract itself from a number of conflicts: a withdrawal from India which might have caused led to mass casualties; from the conflict in Palestine; the Malayan emergency; and the Korean War.

Other European governments also faced their own mix of domestic and foreign crises - a number facing civil war, such as Greece and Italy; as well as the unravelling of colonial empires, (e.g. France, Italy and Holland. In due course, Belgium and its Congo) compounded by deep problems in feeding themselves. Britain had an interest in Europe both through its hard fought war to liberate it but also from its longstanding aversion to the Soviet regime for which it had already planned to go to war with if the need arose [6].

Indeed, Europe and the Soviet threat - and the concern over whether US support would be forthcoming would ultimately lead to two British actions with long-term consequences: the decision to secretly develop its own atomic weapons - with "a bloody Union Jack on it" to quote its then Foreign Minister, Ernest Bevin; and the above establishment of NATO famously spoken of as a means to "keep the Americans in, the Russians out and the Germans down" in Europe.

As noted in the first paper, Atlee was keen to obtain reassurance from Truman on the US commitment to Europe during the onset of the Korean War in 1950.

The question left unanswered from the Atlee years remains ultimately why did the government not move to take a leading role in the European project? On 18 April 1951, France, West Germany, Italy and the three Benelux countries (Belgium, Luxembourg, and the Netherlands) signed the Treaty of Paris establishing the European Coal and Steel Community (ECSC), which would be the first step towards the Treaty of Rome being signed in 1957 and the creation of what would later become the European Union.

Reading the several biographies of Atlee - and Atlee was one of the few constants throughout 19451951 given the deaths and retirement of many of the leading Cabinet ministers and remained the Leader of the labour Party until 1955 - there is little sense of what might be termed "vision" or at least not of what Europe might become under British leadership. There was, however, a considerable amount of wishful thinking by Atlee and others that the British Empire might be transformed into a "Socialist commonwealth" [3, p. 44]. This would also be adopted by Atlee's successor, Hugh Gaitskell who once said that joining the European project would mean "the end of Britain as an independent European state, the end of a thousand years of history!" [4, p.414].

One possible reason for this aversion to the European project was that the mining and steel sectors which were to be regulated by the six founders - were major sources of employment in the UK and also of support for the Labour Party. In 1950, there were 693,000 mineworkers and around 350,000 steelworkers. It was Herbert Morrison, the deputy leader of the Labour Party and Foreign Secretary at the creation of the ECSC who famously remarked: "The Durham Miners will never wear it" [21, p. 64].

While the Labour Party dwelled on upsetting one of its interest groups or waxed over the latent promise of a Socialist Commonwealth, the Conservatives returned to power in December 1951 under the redoubtable Churchill.

\section{The Churchill Intermission: Empire over Europe}

Churchill has been feted as the "Greatest Englishman of the Twentieth Century" in regular polling and enjoys almost mythical status in the UK with books and films regularly released on his life and works. Churchill had also demonstrated an intense affinity for the Imperial project: as Minister for Air (and later for Colonial affairs,) he had ordered the suppression of a rising in Iraq in 1919 by the bombing of villages by the Royal Air Force and considered use of poison gas; and had sought the arrest of Gandhi and suppression of the Indian independence movement. "I have not become the King's first minister", Winston Churchill famously remarked in 1942, "in order to preside over the liquidation of the British Empire" [12].

Indeed, the future of the British Empire was to become a matter of friction between the British and the Americans in their wartime "special relationship". Roosevelt was critical of the British refusal to face up to the demands for Indian independence. There was a view in Washington that the Atlantic Charter of August 1941 - the clarion call for asserting liberal values in the face of Nazism and fascism signed by both the US and the UK - was being honored more in the breach by British desires to maintain its imperial project. Rather than the smooth transition from one superpower to the other, there was a considerable measure of 
co petition, where there was co operation in a number of critical areas such as defense and intelligence, as well as a common approach to shared enemies; in others: extreme competition, particularly when it came to markets and resources e. $g$ oil in the Middle East - see later for Iran - and based on the influence wielded by important domestic lobbies [1].

Indeed, an example of the latter, given past issues of morality and guilt (the US under Roosevelt had sat on its hands in the 1930s with Jewish migrants denied access to the USA), Truman would push for the British to terminate its mandate in Palestine and quickly exit; thereby leaving the new state of Israel to emerge victorious in the wake of mass ethnic cleansing and much bloodletting.

The US would push to insert its oil majors in Saudi Arabia - essentially a British made construct for King Ibn Saud. We have noted the joint SIS/CIA operation to reverse the Mossadegh nationalization of British oil interests in Iran in 1953. The payback to the USA would encompass US oil companies receiving a $20 \%$ stake in the new consortium to develop Iran's oil concessions.

\section{British options: Forewarned but forgone}

It is often said that it is best to keep all one's options open. The argument is that it is often best not to take precipitate action, to rush to judgement. Far better is to wait on events and if matters come to pass then to take the best course of action. A "stitch in time saves nine" as the saying goes. Matters can reveal themselves and the costs / benefits of adopting one course of action or another become more obvious and "rational decision making" takes precedent over whim or whimsy.

That said, leaving your options open is in itself also an option. Harold Wilson, Prime Minister in 1964-1970 and again in 1974-1976, once said: "A decision delayed is a decision made". Keith Joseph a Cabinet minister in the Thatcher government said, perhaps in a similar vein the same: "To not have an industrial policy is of itself a policy". Leaving options open is often a decision in itself and occasionally incurs its own costs.

Britain, by maintaining all its perceived options open was also delaying decisions - some of which it could barely imagine might present costs or benefits to it. This was a curiosity. Britain wished to maintain its empire (much as France wished do - its defeat in Dien Bien Phu would force it out of Vietnam in 1954 and the bloody Algerian conflict would only conclude in 1962); it sought to maintain the security and stability in Europe along with its fellow NATO members - France would leave the political side in 1964 but all knew if "the balloon truly went up", France would be part of the military alliance.

Britain possessed a considerable number of intelligence and defense arrangements with the USA. The close alliance had not precluded the UK from seeking its own nuclear deterrent in the wake of the US curtailing nuclear cooperation after the war. This was the McMahon Act of 1946 regulating atomic energy but also restricting transfer of data to UK and Canada, both participants in the wartime Manhattan Project. It was a member of "Five Eyes" - a group comprising UK, USA, Canada, Australia and New Zealand which possessed the ability to harvest signals intelligence on a global basis. Henry Stimson, the US Secretary of State had terminated the US cryptography efforts after the First World War with the claim that: "Gentlemen don't read other people's letters". The British still preferred to be gentlemen but also to be of a wiser variety particularly by reading other people's letters.

The Bletchley Park establishment which had broken the German Enigma machine during the war and provided the British with the means to win the Battle of the Atlantic and monitor the Germans in almost real time, had been leveraged into a set of arrangements with the USA and others to listen to and break the codes of enemies, friends and allies, and all nations in between. The British - with American assistance were able to read the diplomatic cables of their Western allies and monitor their plans for the European project. The official diplomatic presence, via ambassadors and embassy staff, as well as unofficial contacts through SIS would have ensured the UK was (and still is) familiar with the intentions of European friends and allies.

Knowledge may not always lead to enlightened decisions - this is the eternal curse of all good civil servants and espiocrats! There are, as the saying goes, those who don't know; and those who don't know they don't know. The British political leadership, with very few exceptions, would find themselves firmly in the camp of the second variety.

The events of the period from what became the Suez Crisis in 1956 to the veto of British proposed membership of the European Economic Community in January 1963 would provide no end of a lesson in how, contrary to the conventional wisdom, options can narrow the longer that they are kept open and that considerable costs can ensue as a result.

\section{The Suez Crisis}

According to Hemingway, in the matter of bankruptcy, it takes place "gradually and then suddenly" (The Sun Also Rises, 1926). By this it is understood that there is a slow protracted process followed by a quick cliff edge drop to oblivion.

States may not actually go bankrupt in strict financial and political terms but events can creep upon the unsuspecting state and, if not agile enough or able to deflect, then can face grave crises. The collapse 
of the British military in France and the defeat and surrender of its principal ally, France, in May 1940, following the phoney war and an even more protracted "phoney peace" of appeasement which would narrow the options dramatically for Britain to one of Churchill becoming war premier or reaching an accommodation with Adolf Hitler. From political insolvency, a going concerns, albeit in diminished form, can still emerge.

Anthony Eden became Prime Minister in 1955 after Churchill completed four years of his last premiership. In Eden's "Downing Street in-tray" was the increasingly complex issue of handling Egypt's new leader, Gamal Nasser.

Britain had become increasingly invested in Egypt's affairs over the nineteenth century and together with the French had taken control of the Suez Canal which had been built between 1859 and 1869 as a link between the Mediterranean and the Red Sea. It constituted a major strategic asset for the British as it straddled the then fast route to Britain's prized colonial possession, India. British naval forces viewed the Mediterranean as a key theatre for operations and a number of installations ranging from Gibraltar on the southern tip of Spain at the narrowest point between Europe and Africa, to Cyprus in the east, as well as the island of Malta (just $80 \mathrm{~km}$ from Italy in the middle), served to underpin British power.

In the Red Sea region, Britain maintained installations in Aden (later part of Yemen) and the Gulf states as well as Kuwait. The latter being of importance in view of its proximity to Iran (where vital oil interests lay as well as Kuwait itself becoming a major oil producer).

The Middle East had become initially an important geo political area of vital interest to Britain as it evolved from an outgrowth of asserting naval power against France and Spain, to a pivot around which a vital sea route to India was secured to an integral source of Economic Power in view of the vast oil reserves contained therein. Indeed, Britain's most important instrument of Military Power, the Royal Navy, was dependent on oil. In one of his former ministerial guises as its political heads - the First Lord of the Admiralty - it was Churchill in 1913 who had provided essential government financial support and backing to a certain William Knox D'Arcy then undertaking a major oil development in the then Persia - this entity, Anglo Persian Oil Company is the direct forbearer of British Petroleum. Churchill initiated the conversion of coal fueled ships to oil. We thus have a triad of Political, Economic and Military Power materializing in this way.

The British military base around Suez, was in its time one of the largest military bases in the world and thus a key instrument to project British power in the region to complement other forms present. Of interest is whether Britain's interests in the Middle East in the initial period of the Second World War took precedence over European security by not using troops there to reinforce the position in France. British military dispositions in France in the run up to the invasion by Germans in 1940 were a mere fraction of what the UK deployed in 1914-1918 to ensure ultimate victory.

The military coup in July 1952 which later removed Egypt's King Farouk would lead to the new regime following through in October 1954 on the 1951 decision to abrogate the Anglo - Egyptian Treaty of 1936 which had formalized the British military base for twenty years. British troops were accordingly withdrawn [7].

Tensions further increased between Egypt and both France and Britain. In the west, the Egyptians supported the Algerian fight for independence from France. Egypt's principal leader, Nasser, was also highly critical of British continued influence in the Middle East with the establishment of the Baghdad Pact involving the then kingdom of Iraq - the Hashemite monarch had been installed on the throne following the First World War, as was the case with Jordan. Matters came to a head in Egypt with US-UK refusal to finance a major construction, the Aswan Dam, to provide irrigation. Nasser turned to the Soviet Union for aid.

Like the British, the Americans also saw Egypt as a pivot for projecting power in the Middle East. Indeed, the Americans had enjoyed close ties to Nasser and the military via the CIA. According to Curtis, op cit, 2018 edn, p 62-3, when UK / USA intelligence services got word of Nasser's major arms deal with Czechoslovakia (essentially fronting for the USSR), the CIA/SIS reached out to the Muslim Brotherhood to overthrow Nasser.

The Americans hoped to create a Middle East version of NATO around Egypt to deny the Soviet Union access to the region. The Americans were also treading a fine line between avoiding a falling out with Nasser on one side and, on the other, wishing to maintain close relations with its two close NATO allies. Nasser's outreach to the Soviet Union for arms purchases and then aid for the Aswan Dam would complicate an already impossible task of trying "to square that diplomatic circle" of conflicting geopolitical interests.

To achieve its own aims, France sought an alliance with Israel - itself an enemy of Egypt. The British were invited to join the Franco-Israel alliance. In secret, the three agreed that Israel would launch an attack on Egypt through the Sinai and that the UK and France would then use this as a pretext for occupying the Suez Canal, which the Egyptians had nationalized as tensions rose.

When Israel invaded, the Anglo - French forces launched their invasion in October 1956. There was considerable uproar in Britain with the Labour opposition highly critical of the military action - at this juncture no one outside a very small circle in government were aware that the operation launched had been contrived in a secret agreement with France. 
While the UK's Military Power combined with France and Israel would accomplish its objectives, its Economic Power would be severely undermined. The UK still viewed the strength of sterling as an important economic aim. The invasion sparked concerns and foreign holders of the currency moved to reduce their holdings. Between 30 October and 2 November, US \$ 50 million was sold and a perennial worry formed in government that the UK would exhaust its foreign reserves trying to maintain its value.

Britain's "lender of last resort" for foreign reserves was the IMF, which the UK had established with the USA at the 1944 Bretton Woods agreement and of which the UK was a significant shareholder (and still remains so).

The USA were furious that the invasion proceeded and would seek to employ all of its available instruments of power to ensure the withdrawal of the Anglo-French forces. It joined the Soviet Union in condemning the invasion in the UN Security Council - an irony not lost on many observers at the time given the Soviet invasion of Hungary to crush the popular uprising. More ominously for the British government, the USA was wielding the economic weapon of ensuring that the IMF - which it controlled - would not assist the UK in overcoming its difficulties but also would sell its own holding of UK government bonds to further exacerbate the financial crisis affecting the UK. The closing of the Suez Canal placed pressure on British oil supplies. Into this mix, Saudi Arabia announced an oil embargo against Britain and France. The US also declined to make up the difference from its own oil supplies.

We will return to the UK's propensity for financial crises in further papers but suffice to say, the then Chancellor of Exchequer (Minister of Finance), Harold Macmillan, placed further pressure on the government by alarmist talk of a possible economic collapse - with his initial gung-ho support for the Suez operation and his subsequent calls to withdraw-at-all-costs, he would be known by his moniker as "First-In-First Out". But Eden, a Conservative premier, appears to have been removed at the American's behest as part of Macmillan`s political manoeuvrings, worthy of the House of Cards [20, p. 352]; Reynolds, op cit, p 192. "Treason doth never prosper: what's the reason? Why, if it prospers, none dare call it treason." A common fantasy peddled by Britain's left is of an American inspired coup against a prime minister of impeccable socialist credentials which would deny the country the "milk and honey" paradise it aspired to and voted for (C Mullin, A Very British Coup, 1987).

Indeed, it is worth noting that Macmillan would later acknowledge his personal failings in the crisis. He later advised Margaret Thatcher at the time of the Falklands War in 1982 not to appoint the then Chancellor as a member of the "war cabinet" being formed by the prime minister. It was advice that she followed.

Anthony Eden would resign as premier in January 1957 and be replaced by Macmillan. In the aftermath, much would be made of Britain's fall from great power status and the humiliation visited upon it by the USA. How true was this?

The withdrawal from the Suez base had already called time on such a large overt presence. In fact, fast forward to 1990s, the US itself would seek to curb such a substantial presence - consider the aftermath of the First Gulf War and, in particular, the US presence in Saudi Arabia. The US would largely turn to more "over-the-horizon" presence to projects its influence over such countries as well as prepositioning arms and materials.

Whilst the US had certainly displaced the UK as an arbiter of the Middle East, it would need to wait until the outcome of the October 1973 War before it moved to displace the Soviet involvement in the Middle East, and in particular, in Egypt, which had been facilitated by Nasser.

Judging by its interventions in the region - Jordan in 1958 alongside the US intervention in Lebanon, Kuwait in 1960, involvement in the Yemen conflict (with Saudi Arabia) fighting Egyptian troops sent by Nasser (and which killed thousands of Nasser's forces) and its intervention in the Arabian Gulf (Oman between 1962-1975), Britain still played an important role in the Middle East and would continue to do so by virtue of its arms sales to the region [9]. Thus, by $1964 \mathrm{i}$. e two years after first intervening, the Egyptians had lost around 15,000 men ( $p$ 691). During this covert war, two hundred thousand people died $-4 \%$ of Yemen`s population. In the light of current events unfolding in that country, one is reminded of the epigram: "plus ça change, plus c'est la même chose".

The problems with sterling would re occur again and again over the coming decades with again calling on the IMF for bailouts of varying sizes. The City of London would not be unduly affected as around this time it played host to the first stirrings of the Eurodollar market. Indeed, the first client for such holdings of dollars deposited outside the USA was the Soviet Union which wished to avoid the Americans impounding their dollar holdings following the Hungarian invasion and trusted British banks to avoid any US sanctions! By the end of 1970, 385 billion Eurodollars were booked offshore and thus a rich source of earnings, commissions and fees for UK banks and a contributing factor to the US' later decision to cut the dollar-gold link.

As far as can discerned, there were no lasting aftereffects on the significant US-UK intelligence relationship. Most probably as this was conducted by a transatlantic defence and security establishment safely cushioned from the whims and fancies of electoral cycles - particularly in the USA. 
Macmillan as Prime Minister: Having his US cake and eating his European cake as well?

The problem would ultimately lay for the UK in its subsequent manoeuvrings. Macmillan's hankering for a strong UK-USA public relationship and being seen as the US's most loyal ally most assuredly blinded him to how this would be perceived by European allies, particularly the French. Here, the German Chancellor Adenauer saw an opportunity to pursue closer relations with the French. Indeed, Macmillan's attitude of the British playing "the Greeks to the "Roman' Americans" as Britain supposedly handed over its leading role to the US was surely as poor an interpretation of history (the Romans conquered Greece in second century BC) as the poor conduct of diplomacy in Europe's chancelleries given French perceptions of "perfidious Albion" both in the midst and aftermath of Suez as the UK wilted under US power and, as a result, the UK faced a growing Franco-German rapprochement.

Eden had not dispatched a senior minister to sit in on the Messina Conference in 1955 and Macmillan had not engaged in the Treaty of Rome in 1957 which essentially created the European Economic Community. Options previously open to the UK were now starting to close [21].

Indeed, a constant theme arising particular in the establishment of the Coal and Steel Community, the Messina Conference and after, is British political leaders' firmly held mindset that all would come to naught from such European meetings and to be dismissive of the Europeans' moves to achieve their common project. This seems to have become a working assumption by all UK governments, even after European membership was achieved. This would apply at each step in the process of "an ever closer union" whether it be the setting up of the Exchange Rate Mechanism, the creation of the common currency and so on. This has even extended into the post Brexit referendum period. The Foreign Secretary airily enquired where would Italy be without British consuming their prosecco. The constant refrain is the EU needs the UK; thus German manufacturers will ensure Merkel provides the UK with what it wants. The list of self imposed illusions and delusions could go on. The only constant is that British politicians have underestimated their European colleagues and always appear surprised when the actual outcome was different from that expected. This surely constituted the triumph of hope over experience! To misquote Talleyrand, British politicians "had learned nothing, and forgotten everything".

A final contributing event was Britain's search for a viable nuclear deterrent. A nuclear deterrent deployed by plane was slowly losing its credibility in the face of being capable of penetrating heavy Soviet air defenses and the fact that the USSR had launched Sputnik into space in 1957 meant that a nuclear bomb delivered by missile was to be the wave of the future. Britain's attempts to devise its own missile system, Blue Streak, had been terminated in 1960 and increasingly it had turned to a US system, Skybolt, as its alternative. To stay in the nuclear race after the US decision to cancel Skybolt, Macmillan lobbied President Kennedy for Polaris missiles which could be based on submarines. An agreement to supply Polaris was reached between the UK and USA on 21 December 1962.

The optics of the increased nuclear cooperation between the US and UK were not lost on the French.

Macmillan would not be the first prime minister to misjudge the importance of personal relations with European leaders. John Major would misjudge his relationship with German Chancellor Helmut Kohl over the latter's ability to override his central bank head during the run-up to Black Wednesday when the UK left the ERM (see first paper). Tony Blair would misjudge his relations with both the French President Chirac and the German Chancellor Schroder in the run up to the fateful decision to invade Iraq. David Cameron would misjudge the extent of his relations with Angela Merkel to secure EU concessions ahead of the Brexit Referendum. Mrs. May also appears to follow in this long line.

Macmillan was inclined to believe that his wartime dealings with Eisenhower and De Gaulle would also secure favorable dealings. It is the curse of politicians to overestimate their personal qualities and abilities to secure agreements from other parties on the basis of "personal chemistry". Sometimes this might succeed but often there is just plain "personal alchemy" - the aspiration to turn base elements into gold. Similar rates of success are achieved.

On 25 January 1963, President De Gaulle vetoed the British application to join the EEC. The UK appeared marooned in "no-man's land" with respect to its European options for further advancement. It was surely a far more serious failure of British power than the Suez adventure. Within a period of less than 20 years after its victory in 1945, anointed as one of the "Big 3" powers with the USA and USSR, a key founder of European defense and security cooperation, a key player in the initial economic mechanism for distributing US aid to its fellow Europeans, and leadership of Europe well within its grasp as the two other contenders were mired in assorted government crises (France) or emerging shell-shocked from the rubble to slowly rebuild their lives and cities (Germany), Britain was "set adrift on past memories bliss".

Its European option had just closed.

\section{Conclusion.}

In the first paper, it was noted that, by comparing two episodes in recent British foreign policy, the Korean Peninsula in the 1950s with now; and the decision in the 1990s to ensure the territorial integrity of the Ukraine and the absence of the UK in recent years post Crimean annexation, that the trajectory of British power was in a downward direction. 
An important cause of this was the considerable inattention by British political leaders (particularly of the Conservative Party, but not only) to involvement in the European project. This decision to not engage at the onset essentially depleted British power in all its forms and the formal exit from March 2019 will most assuredly exacerbate this trend.

This paper has sought to demonstrate that Britain's political leaders failed to grasp the opportunity to seek leadership as instead it sought to project its (diminishing) influence on the world stage essentially subsidised by the USA. The Atlee administration had engaged in constructing a European defence and security architecture - and leveraged its influence with the USA to engage them therein - as well as very initial steps in coordinating west European economies to maximise the funds from the Marshall Plan.

From this promising start, the political leaders became entranced with protecting economic interests with Military Power, as subsidised by the USA, and avoided decisions to engage with the European project until it has been closed to it. That was a fateful act and took place just eighteen years after emerging as one of the "Big 3" global powers. Britain played no role in the rules of the game being established by a major economic power on its doorstep.

The next article will examine the course of the UK and its attempts to reverse its decline in power. In particular, it will pay attention to a possible opportunity provided by the Vietnam War.

\section{Література}

1. Arrighi G. The Long Twentieth Century: Money, Power and the Origins of Our Times. UK: Verso, 2009. 432 pp.

2. Arrighi G., Silver B. Chaos and Governance in the Modern World System. USA: Univ of Minnesota Press, 1999. $348 \mathrm{pp}$.

3. Bew J. Citizen Clem: A Biography of Atlee. UK: Riverrun, 2017. 688 pp.

4. Brivati B. Hugh Gaitskell. UK: Cohen Books, Limited, Richard, 1996. 492 pp.

5. Bullock A. Ernest Bevin. UK: Politicos, 2001. 650 pp.

6. Craddock P. Know Your Enemy: How the Joint Intelligence Committee Saw the World. UK: John Murra, 2002. 362 pp.

7. Curtis M. Secret Affairs. Serpents Tail. UK: Serpent's Tail, 2018. 512 p.

8. Curtis M. The Ambiguities of Power. UK: Zed, 1995. 256 p.

9. Dorril S. MI6: Fifty Years of Special Operations. UK: Fourth Estate, 2000. 928 p.

10. Edge D. Britain's War Machine. UK: Penguin, 2012. 480 p.

11. Findlay R., O'Rourke K. Power and Plenty: Trade, War and the World Economy in the Second Millennium. USA: PUP, 2007. 648 p.

12. Hari J. Not his finest hour: The dark side of Winston Churchill. URL: https://www.independent.co.uk/ news/uk/politics/not-his-finest-hour-the-dark-side-of-winston-churchill-2118317.html.

13. Harrison M. The Economics of World War II. UK: CUP, 2000. 309 p.

14. Hennessy P. Never Again: Britain 1945-1951. UK: Jonathan Cape Ltd, 1992. 592 p.

15. Hennessy P. The Prime Minister: The Office and Its Holders Since 1945. UK: Penguin, 2001. 720 p.

16. Mann M. The Sources of Social Power Volume 2 / M. Mann. UK: CUP, 2012. 844 pp.

17. Mullin C. A Very British Coup. UK: Profile Books, 2010. 240 p.

18. Reynolds D. Britannia Overruled. UK: Pearson, 2000. 392 p.

19. Tharoor S. Inglorious Empire. UK: Penguin, 2017. 336 p.

20. Thorpe D. Supermac: The Life of Harold Macmillan. UK: Pimlico, 2010. 896 p.

21. Young H. This Blessed Plot: Britain and Europe from Churchill to Blair. UK: Macmillan, 1999. 528 p. 